\title{
Determinants of productivity in Africa: The role of economic freedom
}

\author{
Cephas Naanwaab* and Osei-Agyeman Yeboah
}

L.C. Cooper Jr. International Trade Center, North Carolina A\&T State University, 1601 East Market Street, Greensboro, NC 27411, USA.

Accepted 27 July, 2013

\begin{abstract}
This paper examines the determinants of multifactor productivity in a cross-country study of 33 African countries. Among others, we specifically focus on the role of economic freedom, and its subcomponents, as defined by the Heritage Foundation/Wall Street Journal Economic Freedom Index (EFI). The empirical results show that the economic freedom index (and most of its components) has a positive and statistically significant impact on the productivity of African nations. The components of economic freedom that are critically important to enhancing productivity of African countries are: Business freedom, investment freedom, financial freedom, property rights freedom and freedom from corruption. We also investigate 'bivariate granger-causality' between economic freedom and total productivity. The results show that economic freedom granger-causes total factor productivity in most of these countries, but the other way around is not true.
\end{abstract}

Key words: Africa, economic freedom, granger-causality, productivity.

*Corresponding author. E-mail: cbnaanwa@ncat.edu. Tel: +1 3362854730.

\section{INTRODUCTION}

Productivity analysis has received a considerable attention among development and agricultural economists over the course of the last five decades. The focus of much of this body of growing literature is on uncovering the sources of productivity growth, with the ultimate aim of explaining the differences in productivity across countries and regions of the world (Fare et al., 1994; Coelli and Rao, 2003). Fare et al. (1994) presents an in-depth analysis of productivity growth among 17 OECD countries, by constructing Malmquist productivity indexes, which they decompose into technical change and efficiency change. Coelli and Rao (2003) study the determinants of agricultural total factor productivity growth among 93 countries of the world, including 26 African countries (Appendix 1), and some 40 other developing countries from Asia and South-Central America. These studies and others have found evidence in support of convergence of productivity growth of developing countries to the level of developed countries. ${ }^{1}$ Productivity growth, which embodies technological advancement, is the source of economic growth, and can offer a path to sustained poverty reduction, job creation and higher wages (Isaksson, 2007). The importance of productivity growth, especially in the case of African countries, is best underscored by Blinder and Baumol. "...over long periods of time, small differences in rates of productivity growth compound, like interest in a bank account, and can make an enormous difference to a society's prosperity. Nothing contributes more to the reduction of poverty, to increases in leisure, and to the country's ability to finance education and public health " (Blinder and Baumol 1993:778).

\footnotetext{
${ }^{1}$ Examples of studies that found evidence for convergence are Baumol (1986), Barro and Sala-i-Martin (1992, 1995), Bernard and Durlauf (1995), Tsangarides (2001) and Lee and McAleer (2004).
} 


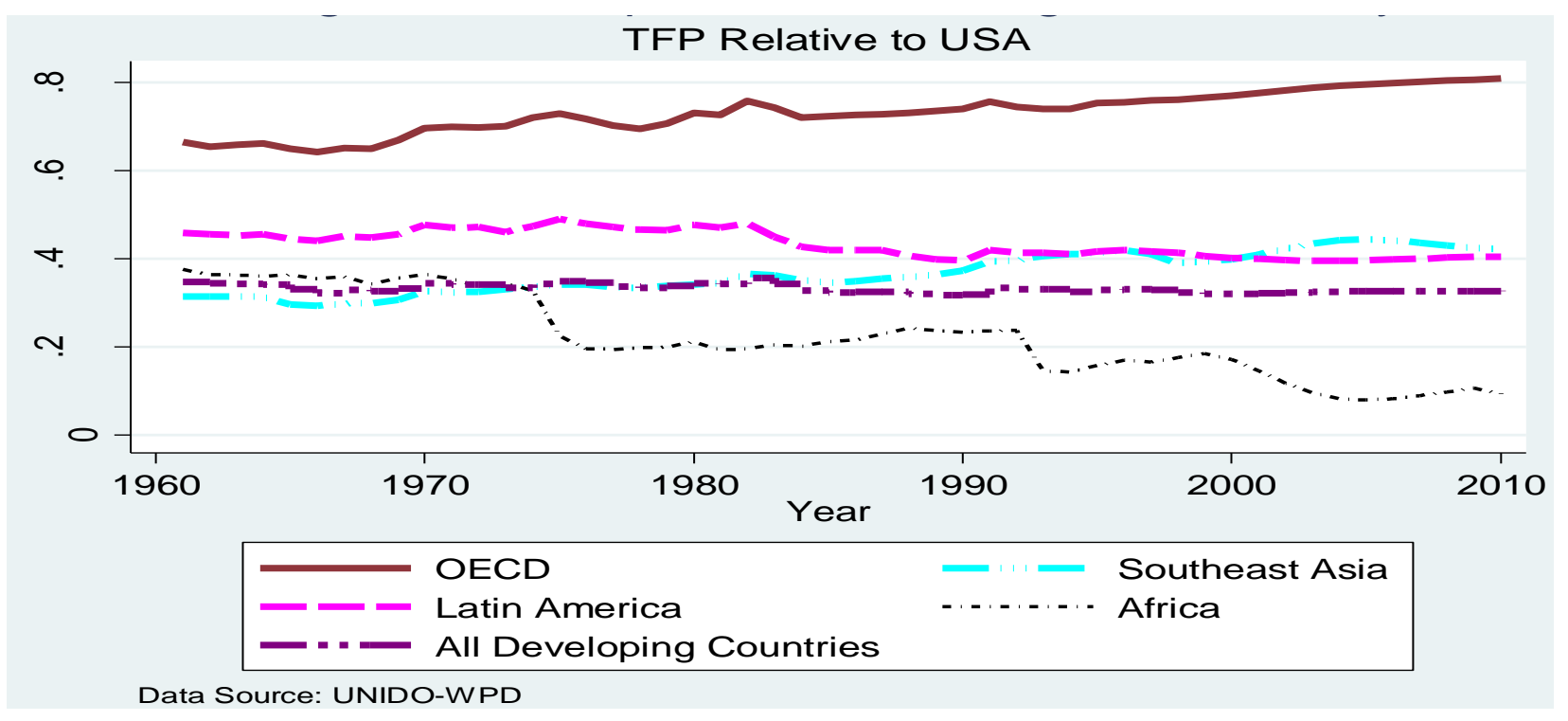

Figure 1. Comparison of average productivity.

Figure 1 shows that average productivity among African countries has typically been low in comparison with other developing countries in Southeast Asia and Latin America. What is more intriguing is that, rather than increasing, productivity actually seems to be falling among African countries while productivity of their counterparts in Southeast Asia is increasing (Figure 1). The fortunes of too many poor people, particularly in Africa, and the developing world at large, could very well depend on the ability of their countries to put in place policies and institutional structures that promote productivity growth. Mbaku (2003) states that the real problem (with Africa) is not lack of resources, ignorance, or incompetence, but rather weak institutions and perverse incentives. What Africa needs is economic freedom and limited government if it is to realize its full potential. An understanding of how economic freedom impacts productivity is therefore paramount, in view of the fact that productivity growth spurs economic growth. This paper contributes to the literature by exploring the factors that lead to increases in productivity, by focusing exclusively on economic freedom.

The Heritage Foundation's 2012 index of economic freedom has classified nearly 40 African countries as either repressed or mostly un-free (HFI, 2012). The Fraser Institute's Economic Freedom of the World (EFW) 2011 report also classified more than half of African countries as least free or falling below the third quartile on the EFW index (Gwartney et al., 2011). The authors of the EFW found that the economies of countries with more economic freedom tend to grow more rapidly. Moreover, income per capita, educational quality, quality of health care, literacy rates, and life expectancy tend to increase with more economic freedom (Gwartney et al., 2011). On the other hand, countries with less economic freedom tend to have extreme poverty rates. The objectives of the present paper are twofold; firstly, we investigate the presence of statistical relationship between economic freedom and productivity. To this end, we test for granger-causality between economic freedom and productivity. Secondly, the study seeks to determine which sub-components of economic freedom affect productivity.

\section{LITERATURE REVIEW}

Productivity can be defined in various ways, depending on whether one is looking at firm-level, industry level or economy-wide productivity. Broadly defined, productivity refers to the ratio of output of goods (and services) to an index of total inputs used in producing that output (Griliches, 1979). At the firm- or industry-level, productivity may be used, simplistically, to refer to labor productivity (output per worker or output per hour). When it comes to national or aggregate productivity however, a more comprehensive measure, such as total factor productivity is often desirable, and this should include not only labor and capital inputs, but also land, natural resources and all other inputs (Diewert and Lawrence, 1999). At the macro-level, therefore, multi-factor productivity (or more appropriately, total factor productivity) may be defined as the ratio of aggregate output produced to aggregate input used.

OECD (2001) defined productivity as the ratio of a volume measure of output to a volume measure of input use, and distinguishes between two broad types of productivity: single-factor productivity, which refers to single input - single output relationship, and multi-factor productivity (total factor productivity), which relates 
multiple outputs to multiple inputs.

Wolf (2007) presents an empirical investigation of factors determining productivity growth in Africa. Labor productivity is found to be affected by, among others, economic incentives index, educational attainment, innovation, and access to foreign technology through FDI. Democracy and infrastructure did not appear to significantly affect productivity. GDP per capita was omitted from the analysis due to high correlation with other included explanatory variables. Isaksson and $\mathrm{Ng}$ (2006) discussed factors that inhibit TFP growth in selected African countries. Specifically, they identified low investments in human capital, infrastructure, $R \& D$, and weak institutions as the major constraints to TFP growth. Pires and Garcia (2011) studied TFP of 75 countries using stochastic frontier analysis to decompose productivity change. They found that differences in productivity are largely responsible for differences in economic growth between developed and developing countries.

\section{Economic freedom and productivity}

A number of empirical studies have been undertaken on the relationship between economic freedom and growth. Most of these studies (Ayal and Karras, 1998; Gwartney et al., 1999; Heckelman, 2000; De Haan and Sturm, 2000; Dawson, 1998, 2003) have reached conclusions that economic freedom- as measured by limited government interference, enforcement of private property rights, personal choice and freedom of enterprisepromotes economic growth. In countries where economic freedom is entrenched, the market, as opposed to the state, is the main mechanism by which resources are allocated, and the government only plays the role of enacting and enforcing legal structures, as well as providing an enabling environment and institutions that facilitate free exchange (Mbaku, 2003). The central tenets of an economically free society are personal choice, freedom of exchange and protection of private property (Gwartney and Lawson, 1997). Caudill et al. (2000) performed factor and principal component analyses on popular measures of economic freedom. Their study revealed that economic freedom is not a onedimensional concept and thus advocated for the use of several measures in ranking countries rather than using an overall index which mis-represents the economic freedom rankings of many developing countries. In their comparative study of three different economic freedom indices, provided by the Fraser Institute, Heritage Foundation/Wall Street Journal, and Heritage and Freedom House, they concluded that all three performed fairly well against a statistical best single index. The idea that economic freedom is multi-dimensional is supported by the findings of Ayal and Karras (1998), in which they determined that six out of thirteen components of economic freedom measures were statistically significant in determining multifactor productivity and growth.

All other things remaining the same, countries with high economic freedom have higher productivity and higher income per capita. The EFW index (Gwartney and Lawson, 2002) is highly correlated with income per capita and economic growth. Looking at Figure 2, it is clear that countries that have put in place strong economic institutions, such as Botswana and South Africa, are also the ones that are performing well economically. This is clear indication that in the case of African countries, a positive relationship exists between economic freedom and productivity. Figure 3 , which shows per capita GDP growth rates against economic freedom index, indicates that the top quintile of economically free countries tend to have higher growth rate $(2.56 \%$ on average), while countries at the bottom fifth of the economic freedom index experienced negative growth rate averaging about $0.85 \%$ (Gwartney and Lawson, 2002). Berggren (2003) provides a good review of empirical literature on the relationship between economic freedom and growth. Many of these studies express economic growth, defined by growth of GDP per capita, as a function of economic freedom or its components. Since GDP per capita may also be interpreted as a proxy for productivity, these studies are implicitly concerned with uncovering the impact of economic freedom on productivity. For example, Hanke and Walters (1997) found a positive and significant relationship between GDP per capita and the economic freedom index. Goldsmith (1997) show, in a cross-country analysis, that developing countries that provide their citizens greater protection of economic rights tend to grow faster, have higher per capita incomes, and generally higher living standards.

It is equally important to be able to explain the mechanisms through which economic freedom affects growth and productivity of countries. In pursuit of this goal, Dawson (1998) found empirical evidence from a cross-country study that economic freedom, or crosscountry differences in institutional arrangements, affects growth in two ways; through its direct effect on total factor productivity, and indirectly, through its effect on investment. Ayal and Karras (1998) hypothesized that economic freedom promotes multifactor productivity by enhancing the efficiency with which productive resources are converted into outputs.

\section{MATERIALS AND METHODS}

\section{Data}

We use a balanced panel dataset consisting of 33 African countries covering years 1995 to 2010. The dataset is limited to 33 African countries because these have complete data on the most important variables under consideration. The economic freedom index comes from the Heritage Foundation (HFI) Economic Freedom database. The HFI 'Index of Economic Freedom' is developed by the Heritage Foundation, in collaboration with the Wall Street Journal, and 


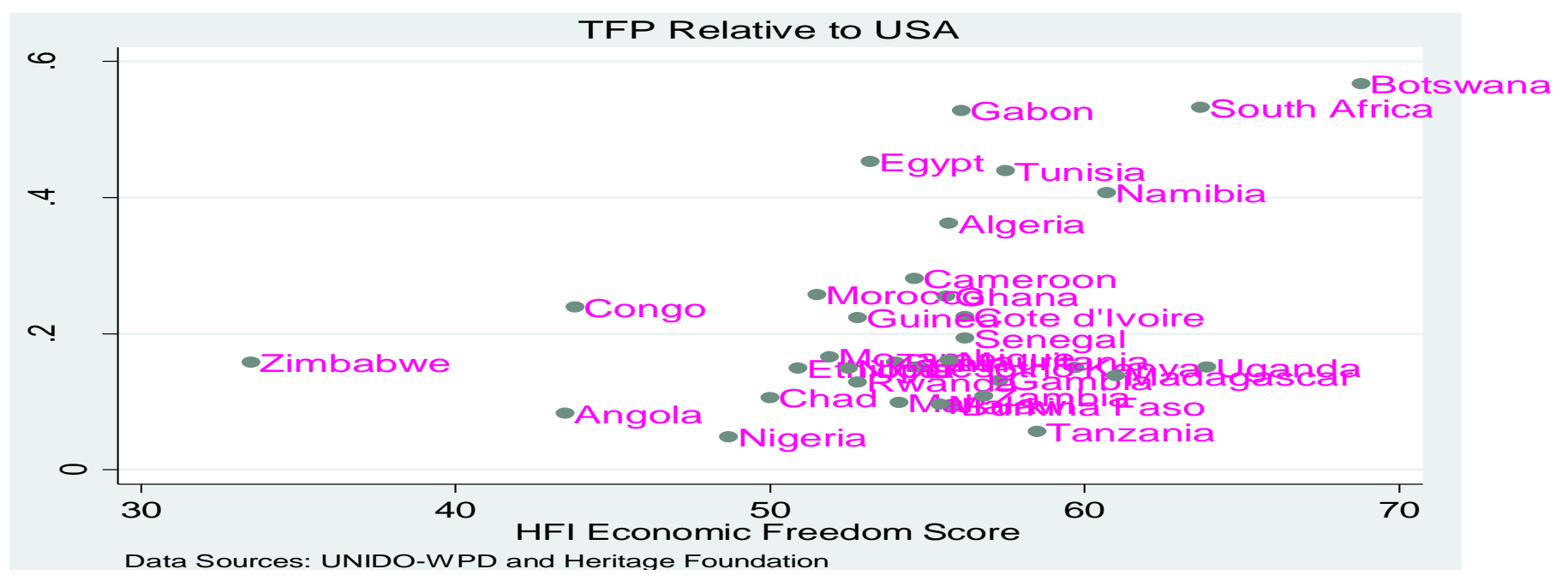

Figure 2. Economic freedom and productivity in Africa.

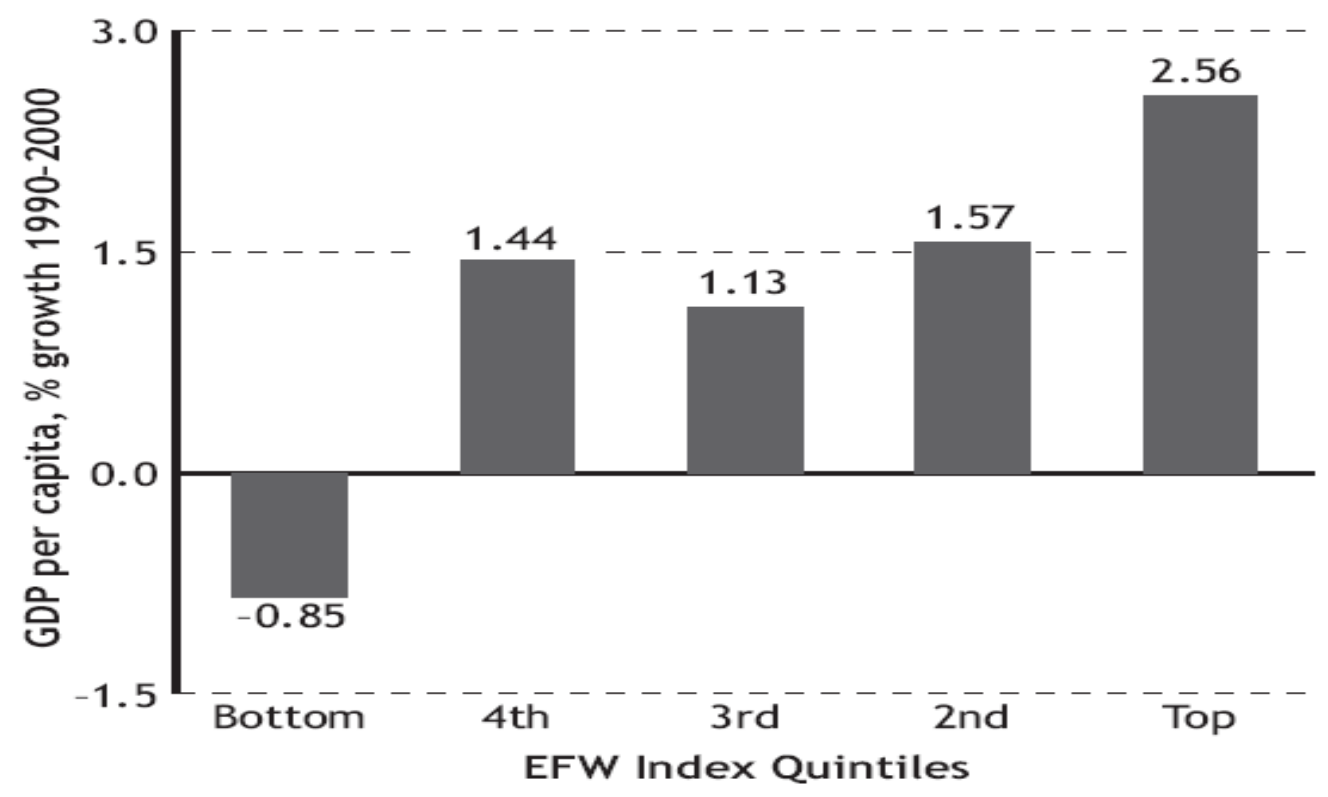

Figure 3. Economic freedom and economic growth. Source: Gwartney et al. (2000).

published annually for all countries in the world. The index is computed as a weighted average of 10 components of economic freedom. ${ }^{2}$ A comparable measure of economic freedom is the Fraser Institute's Economic Freedom of the World (EFW). ${ }^{3}$ The HFI is more consistent in its measurement of the components over the years while the EFW changes both the measures and types of freedoms covered over time. Moreover, the HFI is more broadbased in coverage: the index is based on 10 sub-components while the EFW consists of five sub-components. Thus, it was preferable for us to use the $\mathrm{HFI}$ index.

\footnotetext{
${ }^{2}$ See Beach and Kane (2008) for detailed description of the methodology used to derive the Index of Economic Freedom. The database is available at http://www.heritage.org/index

${ }^{3}$ Gwartney et al. (2011), for details on construction of the index and database http://www.freetheworld.com
}

The economic freedom index $(\mathrm{EFI})$ variable consists of scores on this index for the African countries included in the study. Each component of the $\mathrm{HFI}$ index receives a score on a scale of 0 to 100 (Appendix 2). Each country's score on the ten sub-components are equally weighted to derive an overall score of economic freedom. These 10 sub-components, given equal weight in the computation of the freedom index, are grouped under four pillars (Table 1). Pillar 1 is rule of law and its components are property rights and freedom from corruption. The property rights component measures how each country's laws protect private property, and the extent to which its government enforces such laws. The freedom from corruption component is constructed from the Transparency International's Corruption Perceptions Index (CPI). Pillar 2, limited government, is a composite measure of the size of government. This is comprised of two sub-components, fiscal freedom and government spending. Pillar 3 , regulatory efficiency, comprises 
Table 1. Components of the Heritage Foundation Economic Freedom Index.

\begin{tabular}{|c|c|}
\hline Pillar & Sub-components \\
\hline 1. Rule of law & $\begin{array}{l}\text { 1. Property rights freedom } \\
\text { 2. Freedom from corruption }\end{array}$ \\
\hline 2. Limited government & $\begin{array}{l}\text { 3. Fiscal freedom } \\
\text { 4. Government spending }\end{array}$ \\
\hline 3. Regulatory efficiency & $\begin{array}{l}\text { 5. Business freedom } \\
\text { 6. Labor freedom } \\
\text { 7. Monetary freedom }\end{array}$ \\
\hline 4. Open markets & $\begin{array}{l}\text { 8. Trade freedom } \\
\text { 9. Investment freedom } \\
\text { 10. Financial freedom }\end{array}$ \\
\hline
\end{tabular}

business freedom, labor freedom and monetary freedom. Business freedom is computed from ten other factors, some of which are procedures, days, and costs of starting a business, obtaining a license, and closing a business.

Pillar 4, open markets, consists of trade freedom, investment freedom and financial freedom. Productivity data are obtained from the UNIDO World Productivity Database (Isaksson, 2007). The UNIDO-WPD calculates aggregate total factor productivity (TFP) for 112 countries from 1960 to 2000, and forecasts TFP for 2001 to 2010. By employing different methods and functional forms, the WPD offers a comprehensive measure of productivity that also includes the effects of schooling and health. For a technical description of the methodology used in the TFP computation observed by Isaksson (2007); we also obtained data on technical change and technical efficiency change from the WPD. Productivity data are available through 2010, but data on technical change and technical efficiency change are available up until 2000 from the WPD. In order to extend the dataset to 2010 for the other variables, we forecast these series for 2001 to 2010 using the WPD data from 1960 to 2000 . The forecast method employed is Holt's exponential smoothing.

Other data are culled from the World Development Indicators of the World Bank. These include foreign direct investment (inflows), net official development assistance, trade openness, birth rate (per 1000 people), mobile cellular subscriptions (per 100 people) and labor force.

\section{Analytical model}

A fixed effects panel model is specified to describe the relationship between productivity and economic freedom, controlling for other possible determinants of productivity. In econometric modeling, we often hope that the set of independent variables included in the model explain all of the variability in the dependent variable. This is, however, not always the case, as there are instances of unobserved heterogeneity, that is, factors specific to the individual units that cannot be controlled for, but which nonetheless affect the outcome variable. These tend to be absorbed in the error term, causing potential correlation between the error terms and the included independent variables, a violation of the fundamental Gauss-Markov assumptions underlying least squares estimation (Wooldrigde, 2006). The result of estimating such econometric equations by traditional OLS methods is biased coefficients. ${ }^{4}$ Fixed effects panel models take into account this unobserved heterogeneity between individuals, firms, cities, states, or countries by giving every unit in the study a unique intercept, referred to as the individual or fixed effect (Wooldrigde, 2006). This fixed effect, $\alpha_{\mathrm{i}}$, is best thought of like including dummy variables for $\mathrm{N}-1$ observational units.

Equation (1) shows the specification of one-way fixed effects (spatial variation) model while Equation 2 shows the two-way fixed effects (spatial and temporal variation) model:

$$
\begin{aligned}
& y_{\mathrm{it}}=\sum_{j=1}^{k} x_{\mathrm{i} t, j} \beta_{j}+\alpha_{i}+\varepsilon_{\mathrm{it}} \\
& y_{\mathrm{it}}=\sum_{j=1}^{k} x_{\mathrm{i} t, j} \beta_{j}+\alpha_{i}+\gamma_{\mathrm{t}}+\varepsilon_{\mathrm{it}}
\end{aligned}
$$

Where $\alpha_{\tilde{i}}$ and $\gamma_{t}$ account for cross-sectional (individual-specific) and temporal (time-specific) variations, respectively. Employing these fixed effects models, we account for certain country-and timespecific factors that are important in explaining the differences in productivity across countries. The empirical model is specified as:

$$
\begin{aligned}
& \operatorname{lnTFP}_{i t}=a_{i}+\gamma_{t}+\theta \ln T F P_{i t-1}+\sum_{i=0}^{n} \beta_{l} \ln B F I_{i t-1}+\sum_{i=0}^{n} \delta_{l} \operatorname{lnTC} C_{i t-1}+\sum_{i=0}^{n} \varphi_{l} \ln T E C_{i t-1}+ \\
& \tau_{1} \ln B R_{i t}+\tau_{2} \ln T R_{i t}+\tau_{3} \operatorname{lnODA_{it}}+\tau_{4} \ln F D I_{i t}+\tau_{5} \ln M O B_{i t}+\varepsilon_{i t}
\end{aligned}
$$

Where In denotes the natural log operator, TFP is total factor productivity (an aggregate measure of economy-wide productivity), $E F I$ is the economic freedom index, TC is technical change (captures technological improvement), TEC is technical efficiency change (measures improvement in productive efficiency), $B R$ is birth rate (per 1,000 people), TR is the volume of trade as a percent of gross domestic product, $O D A$ is net official development assistance received per worker, $F D I$ is net inflows of foreign direct investments per worker, and $M O B$ is mobile cellular subscriptions per 100 people.

The included right hand side variables are presumed to be productivity-enhancing or productivity-limiting. For example FDI and ODA could be considered as proxies for investments per-worker. In countries where the rate of investment is higher, worker productivity tends to increase, which in this case can be interpreted as productivity-enhancing investments. MOB (mobile phone subscriptions per 100 people) is a proxy for ease of communication and transacting business, which is hypothesized to increase worker productivity. The birth rate variable (BR) is included to proxy for fertility rate, and accounts for the importance of female labor productivity. Higher fertility rates are consistent with lower female labor force participation rates, and thus, it is postulated that this variable negatively correlates with total factor productivity in a given country. It is also worthwhile to investigate which sub-components of the Economic Freedom Index are more important determinants of productivity. Thus, in Equation 4, we replace the EFI variable with 9 sub-components of the EFI index for which we have complete data (labor freedom not included because it has a lot of missing data). But before doing that, it is important to ensure that there is no high collinearity among these sub-components. The correlation matrix of these economic freedom components is shown in Table 2. We realize that the highest correlation among them is 0.507 between freedom of property rights and freedom of investment. That means that countries that score highly on freedom of property rights also tend to have high freedom of investment. The other correlations are insignificant, which signals that multi-collinearity may not pose a

\footnotetext{
${ }^{4}$ Tsangarides (2002) addresses the twin problems of omitted variable bias and endogeneity bias in the context of cross-sectional and panel data. A GMM estimator that corrects for both biases is discussed.
} 
Table 2. Correlation matrix of components of economic freedom.

\begin{tabular}{|c|c|c|c|c|c|c|c|c|c|}
\hline & Business & Trade & Fiscal & Government & Monetary & Investment & Financial & $\begin{array}{c}\text { Property } \\
\text { rights }\end{array}$ & Corruption \\
\hline Business & 1 & & & & & & & & \\
\hline Trade & -0.136 & 1 & & & & & & & \\
\hline Fiscal & 0.005 & 0.331 & 1 & & & & & & \\
\hline Government & -0.116 & -0.044 & -0.064 & 1 & & & & & \\
\hline Money & 0.144 & -0.023 & -0.065 & 0.155 & 1 & & & & \\
\hline Invest & 0.318 & 0.064 & 0.172 & 0.014 & 0.281 & 1 & & & \\
\hline Finance & 0.164 & 0.182 & 0.166 & -0.009 & 0.18 & 0.466 & 1 & & \\
\hline Property & 0.489 & 0.029 & 0.138 & -0.175 & 0.092 & 0.507 & 0.461 & 1 & \\
\hline Corruption & 0.377 & -0.016 & 0.148 & -0.265 & -0.005 & 0.299 & 0.317 & 0.374 & 1 \\
\hline
\end{tabular}

problem, thus, allowing us to re-estimate Equation (3) as

$$
\begin{aligned}
& \ln T F P_{\mathrm{it}}=\alpha_{\mathrm{i}}+\gamma_{\mathrm{t}}+\theta \ln T F P_{\mathrm{it}-1}+\sum_{j=1}^{9} \alpha_{j} \ln E F I_{\mathrm{it}-\mathrm{l}, j}+\sum_{i=0}^{n} \delta_{\mathrm{l}} \ln T C_{\mathrm{it}-\mathrm{l}} \\
& +\sum_{\mathrm{l}=0}^{n} \varphi_{\mathrm{l}} \ln T E C_{\mathrm{it}-\mathrm{l}}+\tau_{1} \ln B R_{\mathrm{it}}+\tau_{2} \ln T R_{\mathrm{it}}+\tau_{3} \ln O D A_{\mathrm{it}} \\
& +\tau_{\mathrm{g}} \ln F D I_{\mathrm{it}}+\tau_{5} \ln M O B_{\mathrm{it}}+\varepsilon_{\mathrm{it}}
\end{aligned}
$$

Where $E F I(j=1,2, \ldots, 9)$ are the sub-components of the Heritage Foundation Index of economic freedom (Table 1).

\section{Bivariate Granger-causality test}

We test the working hypothesis that economic freedom "Grangercauses" productivity in Africa. Bivariate Granger Causality (Granger, 1969; Sims, 1972) is used to test whether past values of the economic freedom index contain information that could possibly predict values of productivity in subsequent years, accounting for the history of the latter. We posit that granger causality runs unidirectionally from economic freedom to total factor productivity. While this serves as a working hypothesis, we acknowledge that feedback or reverse causation is possible, and thus consideration is also given to the instance where granger-causality is bi-directional. Granger-causality may not necessarily indicate the presence of a causal effect; as such care should be exercised in its interpretation, lest one commits a post-hoc-ergo propter hoc error. A vector autoregressive (VAR) model, Equation 5 provides a natural way of testing granger causality when there are many variables:

$Y_{t}=A\left(L_{p} q\right) Y_{t-1}+U_{t}$

Where $Y_{t}$ is a vector of endogenous variables, $A$ is a matrix of coefficients on the lagged (exogenous) variables, $(L, q)$ refers to $q$ polynomials in the lag operator $L$, and $U_{t}$ is the vector of error terms.

For a two-variable case, Granger's test may be expressed by the following two equations:

$$
\begin{aligned}
& y_{t}=c_{1}+\sum_{i=1}^{p} \alpha_{i} y_{t-i}+\sum_{i=1}^{q} \beta_{i} x_{t-i}+u_{t} \\
& x_{t}=d_{1}+\sum_{i=1}^{m} \gamma_{i} x_{t-i}+\sum_{i=1}^{n} \tau_{i} y_{t-i}+u_{t}
\end{aligned}
$$

After estimating these equations, we conduct a chi-squared test on the following null hypotheses. This chi-squared test has been proven to be asymptotically more efficient than the standard F-test in the presence of lagged dependent variables (Hamilton, 1994):
$H_{01}: \sum_{i=1}^{q} \beta_{i}=0$

$H_{02}: \sum_{i=1}^{n} \tau_{i}=0$

Rejection of either one of these null hypotheses signifies unidirectional Granger-causality, and rejection of both means there is bi-directional (feed-back) Granger-causality. Assuming that $x$ refers to economic freedom and $y$ refers to productivity, it follows then, that if $\sum_{i=1}^{q} \beta_{i} \neq 0$ and $\sum_{i=1}^{q} \tau_{i}=0$, then there is a unidirectional Granger-causality from economic freedom to productivity. On the other hand, if $\sum_{i=1}^{n} \tau_{i} \neq 0$ and $\sum_{\bar{i}=1}^{q} \beta_{\bar{i}}=0$, there is an unidirectional Granger-causality from productivity to economic freedom. Finally, if $\sum_{i=1}^{q} \beta_{i} \neq 0$ and $\sum_{i=1}^{n} \tau_{\tilde{i}} \neq 0$, then Granger-causality is bi-directional, so that economic freedom can predict productivity just as productivity can predict economic freedom. Dawson (2003) studied the causality between economic freedom and economic growth by developing Granger-causality tests of freedom versus growth and the disaggregated components of freedom versus growth. Heckelman (2000) also used Granger-causality to test the relationship between economic freedom and growth. It must be pointed out that Heckelman's study also uses the Heritage Freedom Index as its measure of economic freedom. Farr et al. (1998) used the Economic Freedom of the World (EFW) by the Fraser Institute to study causal relationship between freedom and living standards.

\section{EMPIRICAL FINDINGS}

Table 3 presents the results of estimating Equation 3, while the results for model with disaggregated components of economic freedom are shown in Table 4. In Table 3, we compare one-way fixed effects model esults with that of two-way fixed effects ${ }^{5}$. Both the oneway and two-way fixed effects estimates show that economic freedom does have a positive and statistically significant effect on productivity in Africa. All three lagged

\footnotetext{
${ }^{5}$ We have compared fixed effects and random effects in the estimated models. Hausman tests showed that the fixed effects model is preferred. Thus, we chose to report results of the fixed effects model.
} 
Table 3. Panel regression results, dependent variable is LnTFP.

\begin{tabular}{|c|c|c|c|c|}
\hline \multirow{2}{*}{ Variable } & \multicolumn{2}{|c|}{ One-way fixed effects } & \multicolumn{2}{|c|}{ Two-way fixed effects } \\
\hline & Estimate & Standard error & Estimate & Standard error \\
\hline InTFP_lag1 & $0.319^{* * *}$ & 0.030 & $0.321^{* * *}$ & 0.031 \\
\hline $\mathrm{InEFI}^{-}$ & $0.256^{* *}$ & 0.126 & $0.257^{*}$ & 0.131 \\
\hline InEFI_lag1 & 0.085 & 0.151 & 0.073 & 0.155 \\
\hline InEFI_lag2 & -0.081 & 0.138 & -0.063 & 0.144 \\
\hline InEFI_lag3 & -0.031 & 0.113 & -0.042 & 0.117 \\
\hline $\operatorname{lnTC}$ & $0.596^{*}$ & 0.305 & 0.611 & 0.378 \\
\hline InTC_lag1 & 0.169 & 0.317 & 0.147 & 0.398 \\
\hline InTC_lag2 & -0.057 & 0.274 & -0.272 & 0.340 \\
\hline InTC_lag3 & $0.688^{* \star *}$ & 0.210 & $0.812^{\star \star \star}$ & 0.264 \\
\hline InTEC & $0.345^{\star}$ & 0.195 & $0.393^{*}$ & 0.201 \\
\hline InTEC_lag1 & 0.171 & 0.192 & 0.191 & 0.197 \\
\hline InTEC_lag2 & 0.225 & 0.157 & 0.243 & 0.161 \\
\hline InTEC_lag3 & $0.453^{\star * \star}$ & 0.138 & $0.434^{\star \star \star}$ & 0.143 \\
\hline InFDI $^{-}$ & -0.003 & 0.006 & $8.3 e 4$ & 0.007 \\
\hline InODA & -0.013 & 0.011 & -0.017 & 0.013 \\
\hline $\operatorname{lnTR}$ & -0.066 & 0.041 & -0.060 & 0.043 \\
\hline InBR & 0.159 & 0.204 & 0.140 & 0.240 \\
\hline $\operatorname{InMOB}$ & -0.0003 & 0.004 & -0.005 & 0.011 \\
\hline Constant & $-2.443^{\star \star}$ & 0.936 & $-2.305^{\star \star \star}$ & 1.088 \\
\hline No. Cross Sec & 29 & & 29 & \\
\hline Time length & 15 & & 15 & \\
\hline R-squared & 0.77 & & 0.79 & \\
\hline $\mathrm{F}^{\mathrm{a}}$ & 17.73 & $p<0.0001$ & 16.25 & $p<0.0001$ \\
\hline
\end{tabular}

${ }^{a}$ F-statistic for testing $\mathrm{H}_{0}$ : No fixed effects, Note: ${ }^{* *} \mathrm{p}<0.01$, ${ }^{* *} \mathrm{p}<0.05,{ }^{*} \mathrm{p}<0.1$. Maximum lag of 3 was chosen based on AIC/BIC criteria.

economic freedom index variables are not statistically significant but the contemporaneous effect is very strongly significant. This may suggest that there is a contemporaneous or short run effect but no long run effect in the relationship between economic freedom and productivity. The short run effect on total factor productivity as a result of $1 \%$ increase in the economic freedom index is $0.25 \%$. Dawson (1998) in a crosscountry study, covering some 85 countries, also found empirical evidence that economic freedom positively affects total factor productivity. In line with the postulates of the endogenous growth theory, we find evidence that technological improvement, through its direct effect on increasing productivity, may lead to growth. Both technical change and technical efficiency change in our models are strong determinants of total factor productivity in Africa. Contrary to expectations, we do not find empirical evidence that net official development, foreign direct investment, and mobile cellular usage increase productivity. The advent of the cellular phone in Africa reduced communication problems greatly, and as such it was expected that businesses and other transactions can be carried out much more quickly and efficiently, than decades ago when low telephone connectivity meant people necessarily had to travel longer distances to undertake simple transactions (Lee and Gardner, 2011; Jesen, 2007; Qiang et al., 2009).

Quite to the contrary, our models show that mobile telephone usage reduces productivity. It might be the case that while cellular phone usage is certainly good for the individual as a communication tool; it does not translate into increased productivity at the work place. The Official Development Assistance (ODA) received per capita does not increase productivity as would be expected. The birth rate, foreign direct investment, and the volume of trade do not significantly affect the level of productivity. In Table 4, we show results of estimating Equation 4, where the focus is on looking at the effect of individual sub-components of the freedom index on productivity. Invoking the assumption that these subcomponents are orthogonal to each other (Table 2), Equation 4 was estimated, and the results indicate that three of these freedoms (business, monetary and investment freedoms) are positively associated with productivity. Again, the lagged effects of these subcomponents are insignificant, except for monetary freedom, where both the first and second lags are negative. 
Table 4. Effects of sub-components: Dependent variable: InTFP.

\begin{tabular}{|c|c|c|c|c|c|}
\hline \multirow{2}{*}{ Variable } & \multicolumn{5}{|c|}{ Fixed effects } \\
\hline & Estimate & Standard error & Variable & Estimate & Standard error \\
\hline InTFP_lag & $0.299^{\star \star *}$ & 0.031 & Inpropertyf & -0.041 & 0.031 \\
\hline Inbusinessf & $0.184^{* \star *}$ & 0.053 & Inpropf_lag1 & 0.047 & 0.035 \\
\hline Inbusinessf_lag1 & -0.094 & 0.061 & Inpropf_lag2 & 0.011 & 0.029 \\
\hline Inbusinessf_lag2 & -0.034 & 0.054 & Incorrupf & 0.013 & 0.022 \\
\hline Intradef & -0.025 & 0.025 & Incorrupf_lag1 & -0.015 & 0.023 \\
\hline Intradef_lag1 & 0.009 & 0.023 & Incorrupf_lag2 & 0.013 & 0.019 \\
\hline Intradef_lag2 & 0.0003 & 0.020 & InTC & -0.117 & 0.272 \\
\hline Infiscalf & 0.083 & 0.088 & InTC_lag1 & 0.054 & 0.284 \\
\hline Infiscalf_lag1 & 0.032 & 0.092 & InTC_lag2 & 0.525 & 0.206 \\
\hline Infiscalf_lag2 & -0.081 & 0.071 & InTEC & -0.138 & 0.178 \\
\hline Ingovsf & 0.047 & 0.038 & InTEC_lag1 & 0.007 & 0.174 \\
\hline Ingovsf_lag1 & 0.037 & 0.037 & InTEC_lag2 & $0.441^{\star \star \star}$ & 0.137 \\
\hline Ingovsf_lag2 & -0.035 & 0.034 & InFDI & -0.006 & 0.005 \\
\hline Inmoneyf & $0.218^{* * *}$ & 0.042 & InODA & 0.016 & 0.011 \\
\hline Inmoneyf_lag1 & $-.096^{\star *}$ & 0.046 & $\operatorname{lnTR}$ & $-0.074^{\star *}$ & 0.039 \\
\hline Inmoneyf_lag2 & $-.069^{*}$ & 0.041 & InBR & 0.027 & 0.197 \\
\hline Ininvestmentf & $0.104^{* * *}$ & 0.034 & InMOB & -0.0002 & 0.005 \\
\hline Ininvestmentf_lag1 & -0.041 & 0.037 & Constant & $-2.022^{\star *}$ & 0.977 \\
\hline Ininvestmentf_lag2 & -0.037 & 0.031 & & & \\
\hline Infinancialf & -0.001 & 0.028 & & & \\
\hline Infinancialf_lag1 & 0.007 & 0.032 & & & \\
\hline Infinancialf_lag2 & -0.033 & 0.027 & & & \\
\hline No. groups & 29 & & & & \\
\hline R-squared & 0.84 & & & & \\
\hline $\mathrm{F}^{\mathrm{a}}$ & 18.99 & $p<0.0001$ & & & \\
\hline
\end{tabular}

${ }^{a}$ F-statistic for testing. $\mathrm{H}_{0}$ : No fixed effects. Note: ${ }^{* * *} \mathrm{p}<0.01,{ }^{* *} \mathrm{p}<0.05,{ }^{*} \mathrm{p}<0.1$. Maximum lag of 2 was chosen based on AIC/BIC criteria.

\section{Economic freedom granger-causes productivity}

We conducted bivariate granger causality tests between economic freedom and total factor productivity for all countries in the sample. Equations 6 and 7 were estimated for each of the countries, using two lags. The maximum lag length of 2 was chosen following the general to specific rule, that is, we start with an arbitrarily large number of lags (say $p$ ) and drop insignificant lags until all remaining lags are significant. Granger-causality results are presented in Table 5. Column two presents results of testing the null hypotheses in Equations 8 and 9. These two null hypotheses are tested for each country: Economic freedom does not granger-cause productivity $(\mathrm{EFI} \nrightarrow \mathrm{TFP})$ and productivity does not granger-cause economic freedom (TFP $\nrightarrow \mathrm{EFI}$ ). Thus, in column two " $\rightarrow$ "indicates rejection of the null hypothesis and $\rightarrow$ Indicates no rejection. Columns three and four present the chi-squared statistics and p-values for the rejection rules of the null hypotheses. The tests show that granger causality is mostly uni-directional for most of the countries, running from economic freedom to productivity. In 17 of 34 African countries we find evidence that economic freedom granger-causes productivity (Appendix 1). Only in four cases do we have feed-back or bi-directional causation (Mali, Mauritania, Guinea and Niger).

\section{CONCLUSION AND POLICY IMPLICATIONS}

In this paper, we have presented empirical evidence that economic freedom does matter for productivity in the context of African countries. We go further to show that this relationship is not just mere correlation. Granger causality tests reveal that economic freedom precedes productivity in most of these African countries. There is little evidence of reverse granger causality from productivity to economic freedom. Goldsmith (1997) using a large cross-country dataset found that developing countries that scored higher in protecting economic rights of their citizens also tended to grow faster, and scored higher on human development. Gwartney et al. (2011) corroborates this, noting that economic freedom leads to 
Table 5. Granger causality tests.

\begin{tabular}{|c|c|c|c|}
\hline \multirow{2}{*}{ Country } & $\mathrm{EFI}^{\nrightarrow}$ TFP & \multirow{2}{*}{$\chi^{2}$} & \multirow{2}{*}{$p$-value } \\
\hline & $\mathrm{TFP}^{\nrightarrow} \mathrm{EFI}$ & & \\
\hline \multirow{2}{*}{ Algeria } & $\rightarrow$ & 9.9 & 0.007 \\
\hline & $\leftrightarrow$ & 0.01 & 0.936 \\
\hline \multirow{2}{*}{ Angola } & $\nrightarrow$ & 2.52 & 0.284 \\
\hline & $\nrightarrow$ & 0.1 & 0.749 \\
\hline \multirow{2}{*}{ Benin } & $\rightarrow$ & 41.84 & 0.000 \\
\hline & $\nrightarrow$ & 0.42 & 0.519 \\
\hline \multirow{2}{*}{ Botswana } & $\rightarrow$ & 28.7 & 0.000 \\
\hline & $\nrightarrow$ & 0.56 & 0.456 \\
\hline \multirow{2}{*}{ Burkina Faso } & $\rightarrow$ & 23.24 & 0.000 \\
\hline & $\nrightarrow$ & 0.27 & 0.606 \\
\hline \multirow{2}{*}{ Cameroon } & $\rightarrow$ & 31.06 & 0.000 \\
\hline & $\nrightarrow$ & 2.54 & 0.111 \\
\hline \multirow{2}{*}{ Chad } & $\nrightarrow$ & 1.45 & 0.000 \\
\hline & $\nrightarrow$ & 2.83 & 0.092 \\
\hline \multirow{2}{*}{ Congo } & $\rightarrow$ & 12.84 & 0.000 \\
\hline & $\nrightarrow$ & 2.29 & 0.131 \\
\hline \multirow{2}{*}{ Cote d'Ivoire } & $\leftrightarrow$ & 1.57 & 0.210 \\
\hline & $\rightarrow$ & 27.83 & 0.000 \\
\hline \multirow{2}{*}{ Egypt } & $\nrightarrow$ & 0.83 & 0.368 \\
\hline & $\nrightarrow$ & 1.71 & 0.191 \\
\hline \multirow{2}{*}{ Ethiopia } & $\nrightarrow$ & 5.88 & 0.053 \\
\hline & $\nrightarrow$ & 3.67 & 0.055 \\
\hline \multirow{2}{*}{ Gabon } & $\nrightarrow$ & 3.57 & 0.167 \\
\hline & $\nrightarrow$ & 0.58 & 0.456 \\
\hline \multirow{2}{*}{ Gambia } & $\rightarrow$ & 11.49 & 0.003 \\
\hline & $\leftrightarrow$ & 0.71 & 0.398 \\
\hline \multirow{2}{*}{ Ghana } & $\leftrightarrow$ & 5.21 & 0.074 \\
\hline & $\nrightarrow$ & 0.41 & 0.520 \\
\hline \multirow{2}{*}{ Guinea* } & $\rightarrow$ & 8.23 & 0.016 \\
\hline & $\rightarrow$ & 10.7 & 0.001 \\
\hline \multirow{2}{*}{ Kenya } & $\rightarrow$ & 12.84 & 0.000 \\
\hline & $\nrightarrow$ & 0.14 & 0.706 \\
\hline \multirow{2}{*}{ Lesotho } & $\rightarrow$ & 11 & 0.004 \\
\hline & $\nrightarrow$ & 0.71 & 0.399 \\
\hline \multirow{2}{*}{ Madagasca } & $\nrightarrow$ & 1.92 & 0.383 \\
\hline & $\rightarrow$ & 4.49 & 0.034 \\
\hline
\end{tabular}


Table 5. Contd.

\begin{tabular}{|c|c|c|c|}
\hline \multirow{2}{*}{ Malawi } & $\nrightarrow$ & 3.64 & 0.162 \\
\hline & $\rightarrow$ & 4.37 & 0.037 \\
\hline \multirow[b]{2}{*}{ Mali* $^{\star}$} & $\nrightarrow$ & 31.77 & 0.000 \\
\hline & $\nrightarrow$ & 24.28 & 0.000 \\
\hline \multirow[b]{2}{*}{ Mauritani* } & $\nrightarrow$ & 8.25 & 0.016 \\
\hline & $\rightarrow$ & 9.24 & 0.002 \\
\hline \multirow{2}{*}{ Morocco } & $\rightarrow$ & 0.55 & 0.761 \\
\hline & $\nrightarrow$ & 3.06 & 0.080 \\
\hline \multirow{2}{*}{ Mozambique } & $\nrightarrow$ & 9.97 & 0.007 \\
\hline & $\rightarrow$ & 1.04 & 0.307 \\
\hline \multirow{2}{*}{ Namibia } & $\nrightarrow$ & 5.3 & 0.071 \\
\hline & $\rightarrow$ & 3.93 & 0.047 \\
\hline \multirow{2}{*}{ Niger* } & $\nrightarrow$ & 9.18 & 0.002 \\
\hline & $\rightarrow$ & 6.88 & 0.008 \\
\hline \multirow{2}{*}{ Nigeria } & $\nrightarrow$ & 3.83 & 0.147 \\
\hline & $\rightarrow$ & 0.26 & 0.609 \\
\hline \multirow{2}{*}{ Rwanda } & $\rightarrow$ & 22.01 & 0.000 \\
\hline & $\nrightarrow$ & 0.26 & 0.608 \\
\hline \multirow{2}{*}{ Senegal } & $\nrightarrow$ & 5.87 & 0.053 \\
\hline & $\rightarrow$ & 1.44 & 0.231 \\
\hline \multirow{2}{*}{ South Africa } & $\nrightarrow$ & 1.78 & 0.415 \\
\hline & $\rightarrow$ & 0.18 & 0.67 \\
\hline \multirow{2}{*}{ Tanzania } & $\nrightarrow$ & 1.48 & 0.477 \\
\hline & $\nrightarrow$ & 0.63 & 0.426 \\
\hline \multirow{2}{*}{ Tunisia } & $\nrightarrow$ & 27.88 & 0.000 \\
\hline & $\nrightarrow$ & 0.04 & 0.841 \\
\hline \multirow{2}{*}{ Uganda } & $\nrightarrow$ & 12.98 & 0.000 \\
\hline & $\nrightarrow$ & 0.08 & 0.782 \\
\hline \multirow{2}{*}{ Zambia } & $\nrightarrow$ & 4.4 & 0.111 \\
\hline & $\nrightarrow$ & 0.21 & 0.644 \\
\hline \multirow{2}{*}{ Zimbabwe } & $\nrightarrow$ & 4.23 & 0.121 \\
\hline & $\nrightarrow$ & 4.11 & 0.128 \\
\hline
\end{tabular}

EFI $\nrightarrow$ TFP: reads as EFI does not granger-cause TFP. TFP $\nrightarrow$ EFI: reads as TFP does not granger-cause EFI; $\rightarrow$ Means "granger cause" $\rightarrow$ means "no granger. Causation", * indicates bi-directional causation.

more investment, higher per capita incomes and growth rates. We also specifically delineate four sub-components of economic freedom which have the most impactful effect on productivity. These most influential sub- 
components are: business freedom, investment freedom, fiscal freedom and monetary freedom. The first three constitute regulatory freedoms, or to put it bluntly, the extent of government involvement in private transactions. Business freedom is a measure of the ease of starting, operating and closing a business.

Investment freedom means that private entities can freely engage in, and move resources into activities, across different sectors and borders of the country. A number of policy recommendations can be drawn from this study. First of all, African governments can and should promote economic freedom. Most of the recent top performers on the continent- the likes of Botswana, Mauritius, South Africa, Ghana and Rwanda- have shown that this can be done. African governments must promote free markets and strong institutions that will unleash the entrepreneurial abilities of their people. Second, and most importantly, African governments must make the right investments-in human capital development (education, nutrition and health care), infrastructure development (roads, electricity, ports, water and sanitation) and R\&D. The growth of productivity and living standards will depend to a great extent on how well African countries educate and train their workforce.

\section{REFERENCES}

Ayal EB, Karras G (1998). Components of Economic Freedom and Growth: An Empirical Study, J. Develop. Areas 32(3):327-338.

Beach W, Kane T (2008). Methodology: Measuring the 10 Economic Freedoms" Index of Economic Freedom. Retrieved, http://www.heritage.org/index/.

Bernard AB, Durlauf SN (1995). Convergence in International Output, J. Appl. Economet, 10(2):97-108.

Berggren N (2003). The Benefits of Economic Freedom: A Survey, The Independ. Rev. 7(2):193-211.

Baumol WJ (1986). Productivity Growth, Convergence, and Welfare: What the Long-run Data Show, Am. Econ. Rev, 76 (5):1072-1085.

Barro RJ, Sala-i-Martin X (1992). Convergence, J. Political Econ. 100(2):223-251

Barro RJ, Sala-i-Martin X (1995). Convergence Across States and Regions, Brookings Papers on Economic Activity 1:107-182.

Blinder A, Baumol W (1993). Economics: Principles and Policy,Harcourt Brace Jovanovich, San Diego, P. 778.

Caudill SB, Zanella FC, Mixon FG (2000). Is Economic Freedom One Dimensional? A Factor Analysis of Some Common Measures of Economic Freedom, J. Econ. Develop. 25(1):17-40.

Coelli TJ, Rao DSP (2003). Total Factor Productivity Growth in Agriculture: A Malmquist Index Analysis of 93 Countries, 1980-2000. CEPA Working Paper Series No.02/2003.

Coelli TJ, Rao DSP, O' Donnell CJ, Battese GE (2005). An Introduction to Efficiency and Productivity Analysis, $2^{\text {nd }}$ Ed. pp 41-84. Springer.

Dawson JW (1998). Institutions, Investment, and Growth: New CrossCountry and Panel Data Evidence, Economic Inquiry, 36:603-619.

De Haan J, Sturm JE (2000). On the Relationship between Economic Freedom and Economic Growth, European J. Political Econ. 16:215241.

Fare R, Grosskopf S, Norris M, Zhang Z (1994). Productivity Growth, Technical Progress, and Efficiency Change in Industrialized Countries, The Am. Econ. Rev. 84(1):66-83.

Farr WK, Lord RA, Wolfenbarger JL (1998). Economic Freedom, Political Freedom, and Econ. Well-being, Cato J. 18:247-262.
Goldsmith AA (1997). Economic Rights and Government in Developing Countries: Cross-national Evidence on Growth and Development, Studies in Comparative Internat. Develop, 32(2):29-44.

Granger CWJ (1969). Investigating Causal Relations by Econometric Methods and Cross-Spectral Methods, Econometrica, 34:424-438.

Griliches Z (1979). Issues in Assessing the Contribution of Research and Development to Productivity Growth, J. Econ. 10(1):92-116.

Gwartney JD, Lawson RA (1997). Economic Freedom of the World: 1997 Annual Report. The Fraser Institute, Vancouver, B.C.

Gwartney JD, Lawson RA, Holcombe RG (1999). Economic Freedom and the Environment for Economic Growth, J. Institut. Theoret. Econ. 155:643-663.

Gwartney JD, Lawson RA, Samida D (2000). Economic Freedom of the world: 2000 annual Report. The Fraser Institute, Vancouver, B.C http://www.freetheworld.com

Gwartney JD, Lawson RA (2002). Economic Freedom of the World: 2002 Annual Report. The Fraser Institute, Vancouver, B.C. http://www.freetheworld.com.

Gwartney JD, Lawson RA, Hall J (2011). Economic Freedom of the World, 2011 Annual Report, The Fraser Institute, Vancouver, B.C. Retrieved Jan. 31, 2012: http://www.freetheworld.com/datasets_efw.html.

Hamilton JD (1994). Times Series Analysis. Princeton Univ. Press, Princeton, NJ.

Hanke SH, Walters JK (1997). Economic Freedom, Prosperity, and Equality: A Survey, Cato J. 17(2):117-46.

Heckelman JC (2000). Economic Freedom and Economic Growth: A Short-Run Causal Investigation, J. Appl. Econ. 3:71-91.

Isaksson A (2007). World Productivity Database: A Technical Description. Research and Statistics Branch Staff Working Paper 10/2007 Vienna: UNIDO. http://www.unido.org/data1/wpd//ndex.cfm

Isaksson A, Ng TH (2006). Determinants of Total Factor Productivity: Cross-Country Analysis and Country Case Studies. Research and Statistics branch Staff Working 01/2006 Vienna: UNIDO.

Jesen R (2007). The Digital Provide: Information (Technology), Market Performance and Welfare in the South Indian Fisheries Sector, Quarterly J. Econ. 122(3):879-924.

Lee KL, McAleer M (2004). Convergence and Catching Up in the ASEAN: A Comparative Analysis, Appl. Econ, 36 (2):137-153.

Lee SH, Gardner LK (2011). Does the Spread of Mobile Phones Promote Economic Development? Empirical Evidence from South Asia and Sub-Saharan Africa Regions, Southwestern Econ. Rev, 38(1):15-26.

Mbaku JM (2003). Entrenching Economic Freedom in Africa, Cato J. 23(2):217-225.

OECD (Organization for Economic Co-operation and Development) (2001). OECD productivity Manual: Measurement of Aggregate and Industry-level Productivity Growth. OECD, Paris.

Pires JO, Garcia F (2011). Productivity of nations: A Stochastic Frontier Approach to TFP Decomposition, Economics Research International, Article ID 584869, doi:10.1155/2012/584869.

Qiang C, Rossotto C, Kimura K (2009). Chapter 3 Economic Impacts of Broadband, In Information and Communications for Development 2009: Extending Research and Increasing Impact, The World Bank,Washington, D.C.

Sims C (1972). Money, Income and Causality, Am. Econ. Rev, 62:540552.

Tsangarides CG (2002). On Cross Country Growth and Convergence: Evidence from Africa and OECD Countries, J. Afri. Econ. 10(4):355389.

The Heritage Foundation (2012). 2012 Index of Economic Freedom. Washington, D.C.

Wolf S (2007). Encouraging Innovation for Productivity Growth in Africa. African Trade Policy Center of the Economic Commission for Africa. ATPC Work in Progress P. 54.

Wooldrigde JM (2006). Introductory Econometrics: A Modern Approach. $3^{\text {rd }}$ ed., Thomson South-Western, pp. 50-485. 
Appendix 1. Productivity growth by country.

\begin{tabular}{lccc}
\hline Country & $\mathbf{2 0 0 0}$ & $\mathbf{2 0 0 5}$ & $\mathbf{2 0 1 0}$ \\
\hline Algeria & 1 & -0.793 & 1.205 \\
Angola & 0.947 & -4.117 & 6.659 \\
Benin & 1.02 & -1.172 & 0.538 \\
Botswana & 1.025 & -2.878 & -0.42 \\
Burkina Faso & 0.974 & -3.918 & -1.614 \\
Cameroon & 1.046 & 3.601 & -1.206 \\
Chad & 0.969 & 1.153 & -0.313 \\
Congo & 1.078 & 1.713 & -1.85 \\
Cote d'Ivoire & 0.964 & 1.382 & 0.334 \\
Egypt & 1.01 & -0.784 & 0.523 \\
Ethiopia & 1.072 & -2.66 & -0.19 \\
Gabon & 1.008 & 0.472 & -0.447 \\
Gambia & 1.056 & -5.193 & 4.352 \\
Ghana & 1.086 & 2.25 & -4.939 \\
Guinea & 1.003 & -2.792 & -1.226 \\
Kenya & 0.995 & 0.404 & -0.317 \\
Lesotho & 1.016 & 3.21 & 0.699 \\
Madagascar & 0.996 & -2.778 & 1.259 \\
Malawi & 1.017 & -1.979 & 1.133 \\
Mali & 1.007 & -6.035 & 2.719 \\
Mauritania & 1.063 & -6.33 & 6.194 \\
Morocco & 0.972 & -2.927 & 0.278 \\
Mozambique & 1.004 & -0.941 & 0.489 \\
Namibia & 1.004 & 0.182 & -0.096 \\
Niger & 1.072 & -0.285 & -1.931 \\
Nigeria & 0.772 & 4.573 & 8.791 \\
Rwanda & 1.036 & -2.957 & 2.075 \\
Senegal & 1.023 & -1.498 & 0.691 \\
South Africa & 1.018 & -0.486 & 0.035 \\
Tanzania & 1.034 & -2.388 & 0.32 \\
Tunisia & 1.01 & -1.918 & -0.174 \\
Uganda & 0.951 & -1.988 & 1.459 \\
Zambia & 1.017 & -0.848 & 0.309 \\
Zimbabwe & 0.957 & -1.962 & 0.34 \\
\hline
\end{tabular}

Source: World productivity database (Isaksson, 2007).

Appendix 2. Economic freedom score (0-100).

\begin{tabular}{lccc}
\hline Country & $\mathbf{2 0 0 0}$ & $\mathbf{2 0 0 5}$ & $\mathbf{2 0 1 0}$ \\
\hline Algeria & 56.8 & 53.2 & 56.9 \\
Angola & 24.3 & - & 48.4 \\
Benin & 61.5 & 52.3 & 55.4 \\
Botswana & 65.8 & 69.3 & 70.3 \\
Burkina Faso & 55.7 & 56.6 & 59.4 \\
Cameroon & 49.9 & 53 & 52.3 \\
Chad & 46.8 & 52.1 & 47.5 \\
Congo & 40.6 & 46.2 & 43.2 \\
Cote d'Ivoire & 50.2 & 56.6 & 54.1 \\
Egypt & 51.7 & 55.8 & 59 \\
\hline
\end{tabular}


Appendix 2. Contd.

\begin{tabular}{lccc}
\hline Ethiopia & 50.2 & 51.1 & 51.2 \\
Gabon & 58.2 & 54.8 & 55.4 \\
Gambia & 52.7 & 56.5 & 55.1 \\
Ghana & 58.1 & 56.5 & 60.2 \\
Guinea & 58.2 & 57.4 & 51.8 \\
Kenya & 59.7 & 57.9 & 57.5 \\
Lesotho & 48.4 & 53.9 & 48.1 \\
Madagascar & 54.4 & 63.1 & 63.2 \\
Malawi & 57.4 & 53.6 & 54.1 \\
Mali & 60.3 & 57.3 & 55.6 \\
Mauritania & 46 & 59.4 & 52 \\
Morocco & 63.2 & 52.2 & 59.2 \\
Mozambique & 52.2 & 54.6 & 56 \\
Namibia & 66.7 & 61.4 & 62.2 \\
Niger & 45.9 & 54.1 & 52.9 \\
Nigeria & 53.1 & 48.4 & 56.8 \\
Rwanda & 42.3 & 51.7 & 59.1 \\
Senegal & 58.9 & 57.9 & 54.6 \\
South Africa & 63.7 & 62.9 & 62.8 \\
Tanzania & 56 & 56.3 & 58.3 \\
Tunisia & 61.3 & 55.4 & 58.9 \\
Uganda & 58.2 & 62.9 & 62.2 \\
Zambia & 62.8 & 55 & 58 \\
Zimbabwe & 48.7 & 35.2 & 21.4 \\
\hline
\end{tabular}

Source: The Heritage Foundation/Wall Street Journal Index of Economic Freedom. 